\title{
Bilingual teaching talent training in college language courses
}

\author{
JieZhang \\ Zhengzhou university of industrial technology. Henan. China \\ Corresponding E-mail:Jiezher2@126.com
}

Keywords: Bilingual teaching, Teacher training, strategy,

\begin{abstract}
In bilingual teaching, obtaining the knowledge of other disciplines is themain purpose, meanwhile creating the conditions for learners to learn and use the second language, making the students use the second language they should master as much as possible. The ultimate purpose is to enable students to use both native and second language for thinking, switch between the two languages according to the needs of the communication object and the work environment so that they have the ability of bilingual communication and establish their bilingual awareness. But thereal mode of bilingual teaching has not been fully formed in China, it is subject to a certain accumulation of experience, continuous exploration and gradually matures to achieve the desired objectives, thus ensuring human resources for enhancing our country's comprehensive competitiveness.
\end{abstract}

\section{Introduction}

According to the definition by the research fellow Wang Benhua of the Curriculum Teaching Materials of the Ministry of Education, bilingual teaching means that another language except mother tongue is directly applied to the teaching of other disciplines outside the field of language teaching so that learning a second language synchronizes with obtaining the knowledge of other disciplines. With the globalization of the world's economy and China's accession to the WTO, the bilingual teaching has increasingly shown its importance and superiority in our higher education. Through our practice of bilingual teaching for many years, this paper has clarified what is bilingual teaching, explored the necessities and significance of bilingual teaching, and proposed some corresponding innovative strategies. Finally, such a conclusion has been drawn: the emergence of bilingual teaching is the inevitable trend of China's reform and opening up, meeting the international standards, education reform and development. At resent, China's bilingual teaching mainly refers to the combination of Chinese teaching and English teaching. The Former Premier Zhu Rongji have ever proposed bilingual teaching in mid-80s, under the initiative of the Ministry of Education in 2002, many colleges and universities set up bilingual teaching programs. Since then, bilingual teaching rose rapidly all over the country, especially in many colleges and universities, it has not only brought a lot of new experience for English learning, but also brought a new atmosphere of cultural activities on campus, but the query on it never stops, the orientation on it also exists considerable differences, and some people even criticize bilingual teaching. We think that developing bilingual teaching in China has its great necessity, and this is an important move of promoting specialties to the world. With the globalization of the world's economy and China's accession to the WTO, as the world's most universal language, English has been attached more and more importance, the requirements for personnel to apply the English are increasing[1]. On March 8, 2006, Sichuan Daily carried an article "Chinese and English bilingual professionals have an immeasurable prospect in Europe" which had reported that China's enterprises urgently needed the intellectual property professionals who master Chinese and English. This has reflected that it is urgent and necessary for China to implement bilingual teaching and train practical high quality professionals who adapt to the development requirements of globalization and the information society. Some people are worried that bilingual teaching will affect the teaching of disciplines, but practices have proved that bilingual teaching not only don't affect the teaching of disciplines but also can upgrade the teaching of disciplines in foreign language environment. 


\section{THE SIGNIFICANCE FOR PROMOTING THE DEVELOPMENT OF BILINGUAL TEACHING OF CHINA'S HIGHER EDUCATION}

1.The disadvantages are mainly low efficiency in English teaching, poor English application of students, foreign language teaching and specialty teaching is out of joint. The bilingual teaching of Chinese and English can provide students with a good opportunity to practice English. English classroom is the main channel for students to learn English, but the communication and conversation of students in English class lack the authenticity, the students speak English not from their heart, they study English for English, not for using it as a language tool. Bilingual teaching can provide students with more authentic language environment and is conducive to foster the language practice ability of students. Bilingual teaching has offered a favorable environment for students to study English and will greatly enhance the ability of students to apply English. Therefore, the implementation of bilingual teaching provides students with a favorable environment for English learning.

2.The implementation of bilingual teaching can help students accumulate specialized vocabulary and terminology. Specialized vocabulary and terminology are the stumbling blocks to for students to read English. If students can accumulate some specialized vocabulary and terminology while they study special knowledge, then the stumbling blocks to read English will be cleared, they can lay solid foundation for reading the future foreign professional literature, thus acquire and masterthe latest research results of the world more quickly and directly. In addition, Being explained in English, a lot of professional knowledge can be more understandable, so sometimes English can promote students to understand professional knowledge more easily.

3.Bilingual teaching needs to use original editions of foreign teaching materials, which will facilitate us to reform on teaching contents, modes and methods. The implementation of bilingual teaching will firstly meet the problem of teaching materials, for which many teachers recomposeor select and compile the introduced original editions of foreign teaching materials according to the requirements of "Curriculum Standards" of disciplines, while they ensure systematic knowledge, they pay great attention to absorb the advantages of foreign teaching materials, particularly absorb the latest teaching content[2].

4.Many teachers found in the study of original editions of foreign teaching materials that domestic teaching materials focused on deduction, namely, starting from basic concepts, principles, or axioms to proceed reasoning step by step, while foreign teaching materials focused on fostering the ability for foreign students to ask questions, analyze problems and solve problems. For this reason, manyteachers pay attention to absorb foreign advanced teaching methods and apply these methods to their classroom teaching.

5. As we all know, organizing the teaching is an important part of classroom teaching, directly affect the success or failure of a class. How to focus the attention of students on the classroom has been a concern of people. The feelings communication and harmonious atmosphere between teachers and students play a vital role to the success or failure of teaching. If teachers organize teaching by using simple English easily understood by students in the classroom, they can make students have a sense of curiosity and a fresh sense, thus produce an impulse to participate. This will help to attract the attention of students, in the meantime, adjust the classroom atmosphere and make the classroom dynamic. Through some simple English conversations, students and teachers are closely linked to produce novelty and resonance, and ultimately achieve good teaching results.

\section{THE INNOVATIVE STRATEGIES FOR PROMOTING THE DEVELOPMENT OF BILINGUAL TEACHING OF CHINA'S HIGHER EDUCATION}

1. Make Sure the Tasks and Objectives of Bilingual Teaching

Bilingual teaching does not mean the superposition of foreign language teaching and special courses teaching, it is the method for teaching students to learn and understood the contents of special courses by the ways of thinking in a foreign language, the purpose is to nurture students to 
be able to use both native and foreign language to think, switch freely between the two languages according to the needs of the communication object and the work environment so that they have the ability of bilingual communication and establish their bilingual awareness, thus make them become the complex and highly qualified specialists with the international competitiveness. This is the ultimate goal of bilingual teaching.

2. Set up Bilingual Teaching Courses Scientifically According to the Actual Situation of Colleges and Universities

The setup of bilingual teaching courses must meet the requirements of the times. When the school chooses which courses should be conducted by bilingual teaching, it should choose those basic and special courses as the bilingual teaching courses which are very important in the related disciplines in order to ensure the continuity and persistence of bilingual teaching.

3. Train Qualified Bilingual Teaching Teachers

Essentially, bilingual teaching uses two languages as the medium language of teaching and reaches the aim of mastering the foreign language through studying the knowledge of disciplines, therefore, it is the premise of bilingual teaching for teachers to have sufficient language ability, qualified teachers are the priority of bilingual teaching. Schools should carry out strictly the admittance system to the teachers who apply bilingual teaching and select the teachers to undertake bilingual teaching who have the qualified English and professional level, mark out the bilingual teaching courses of different grades and levels with a clear purpose and plan according to the principle of gradual and orderly progress, forming the successive structure of bilingual teaching courses of four grades and a steady echelon formation of bilingual teaching teachers. Bilingual teaching teachers are required to not only have a high level of foreign language, but also be proficient in the professional knowledge of the courses undertaken by them. On one hand, schools should introduce vigorously some complex teachers with a high level of English and expertise, give full play to the role of school personnel studying abroad and select a group of teachers with a long term of studying overseas to form a backbone team of bilingual teaching, on the other hand, schools should increase investment to accelerate the training of bilingual teaching teachers, establish special funds to support some bilingual teaching teachers to study overseas, expand international exchanges, create conditions to hire directly foreign teachers to teach some courses of some specialties[3].

4. Select Appropriate Bilingual Teaching Materials

Selecting appropriate bilingual teaching materials is the basis for bilingual teaching, Generally, schools should select original editions of foreign teaching materials and excellent new bilingual teaching materials recommended by the Ministry of Education. The prominent feature of foreign teaching materials is that their practicability is very strong, this is precisely the weakness of China's teaching materials for many years. Schools also may consider to choose some bilingual teaching materials compiled by a few number of teachers according to the latest theories and knowledge they have already grasped and the characteristics of Chinese students. Some workshops of different levels and different subjects for using original editions of foreign teaching materials should be held regularly to sum up and exchange experiences and explore the means to improve the quality and level of bilingual teaching. Schools should enhance the theory and practice research and construction for using original editions of teaching materials to conduct curriculum reforms of bilingual teaching.

5.Adopt the Gradualism Method of Bilingual Teaching

Studying and applying professional knowledge by bilingual teaching is a gradual process. At present, because the foreign language level of China's teachers and students is limited, teaching by complete foreign language is still difficult for them, there must be a transition phase of gradual improvement. China's bilingual teaching still have some problems such as different foreign language levels of students and lacking of bilingual teaching teachers, which have restricted the development of China's bilingual teaching. Therefore, different schools should start from their own actual situation and take "improving the practical effect of classroom teaching and training the capability of students" as the fundamental principles to develop their bilingual teaching flexibly[4]. (1) Spread after making experiments. The school should select the students with good English to 
establish an experimental class of bilingual teaching, then popularize after conditions mature. (2) Firstly part, then whole. Bilingual teaching is firstly carried out in a certain chapter of the course, after the students improve their English level, and then carried out in the whole course. (3) Teaching in both Chinese and English. To the courses with low English level teachers and students, bilingual teaching can be carried out both in English and Chinese. If some courses aren't ripe for bilingual teaching, teachers can also infiltrate some English special vocabulary into their teaching to improve students’ professional English skills.

\section{Conclusion}

The emergence of bilingual teaching is the inevitable trend of China's reform and opening up, meeting the international standards, education reform and development. But the real mode of bilingual teaching has not been fully formed in China, it is subject to a certain accumulation of experience, continuous exploration and gradually matures to achieve the desired objectives[5-6].On developing bilingual teaching, we must not only follow the basic laws of education but also take a positive method of reform and innovation to promote this work and prevent herding with a rush or a mere formality. With the acceleration of globalization process of economy and politics, a country and nation must expand their global perspective if they want to survive and seek to develop and enhance their international adaptability. The next work we should do is plentiful, complex and arduous. Only by studying and thinking in-depth, analyzing seriously, unifying understanding, clarifying ideas, determining goals and taking the appropriate strategies, we can make the bilingual teaching to develop successfully, thus ensuring human resources for enhancing our country's comprehensive competitiveness.

\section{Reference}

[1] Ye Chusheng. "Brief analysis on the setup of undergraduate curriculum of economics specialties,” Wuhan University Education Study, March 2003.

[2] Liu Ping. "Bilingual education faces new challenges,” Global Education Outlook, October 2001.

[3] Ding Jialing, “Wuhan University actively promotes bilingual teaching," Wuhan University Education Study, September 2004.

[4] Chen Jihong, etc., "To boost the reform of bilingual teaching courses in the form of the education reform project,” China’s University Teaching, April 2004.

[5] Wang Fengmei, "Discussion on the bilingual teaching of economics and management specialties,” Xichang College Journal (Natural Science Edition), January 2007.

[6] Mu Fengying, Liu Hong. "Internationalization of higher education and bilingual Teaching,” Xuzhou Normal University Journal (Philosophy Social Science Edition), June 2004. 